An Introduction to the Philosophy of Language 


\section{Modern Introductions to Philosophy}

General Editor: D. J. o'CONNOR

PUBLISHED

R. F. ATKINSON, Knowledge and Explanation in History

BRIAN CARR, Metaphysics: An Introduction

D. W. HAMLYN, The Theory of Knowledge

BERNARD HARRISON, An Introduction to the Philosophy of Language

w. D. HUDSON, Modern Moral Philosophy

J. TRUSTED, The Logic of Scientific Interference: An Introduction 


\title{
An Introduction to the Philosophy of Language
}

\author{
Bernard Harrison
}


All rights reserved. No reproduction, copy or transmission of this publication may be made without written permission.

No paragraph of this publication may be reproduced, copied or transmitted save with written permission or in accordance with the provisions of the Copyright, Designs and Patents Act 1988, or under the terms of any licence permitting limited copying issued by the Copyright Licensing Agency, 90 Tottenham Court Road, London W1P 9HE.

Any person who does any unauthorised act in relation to this publication may be liable to criminal prosecution and civil claims for damages.

First published 1979 by THE MACMILLAN PRESS LTD

Houndmills, Basingstoke, Hampshire RG21 2XS and London

Companies and representatives throughout the world

ISBN 978-0-333-12044-6 ISBN 978-1-349-16227-7 (eBook)

DOI 10.1007/978-1-349-16227-7

A catalogue record for this book is available from the British Library.

$\begin{array}{llllllll}12 & 11 & 10 & 9 & 8 & 7 & 6 & 5\end{array}$

$\begin{array}{llllllll}03 & 02 & 01 & 00 & 99 & 98 & 97 & 96\end{array}$ 


\section{Contents}

Preface ix

I Names I

I The Autonomy of the Linguistic Sign 3

I. Utterance and sign row

2. The autonomy of language 4

3. Linguistic autonomy and communication 6

4. The constitution of language 8

5. Linguistic creativity 9

6. Dialect and metaphor 12

7. Perceptual discrimination and linguistic discrimination $\quad 14$

8. Ostensive definition 18

9. Causal theories of meaning 19

2 Reference and Generality 22

I. Meaning and reference 22

2. Universals as referents 24

3. Locke on words and ideas 26

4. Abstraction 28

5. Abstraction and simple ideas 30

6. Generality and resemblance $\quad 32$

7. Locke on essences 34

3 General Names and Particulars $\quad 38$

I. Sortal hierarchies $3^{8}$

2. Natural kinds $44^{2}$

3. Logically proper names 43 
II Meaning and Truth 49

4 Sense, Reference and Truth $\quad 5^{\mathrm{I}}$

I. Word meaning and sentence meaning $5^{1}$

2. Frege on number $5^{1}$

3. Sense and reference 55

4. The objectivity of sense $\quad 56$

5. Meaning and truth $\quad 5^{8}$

6. Concept and object $\quad 59$

7. Truth values as referents 6 I

8. Proper names 62

9. Truth and communication $\quad 63$

5 Meaning and Verification 66

I. Truth and knowledge 66

2. The verifiability criterion $\quad 67$

3. The projection of meaning 69

4. Verifiability and nominalism 70

5. Meaninglessness and cognitive content 71

6. The phenomenalist turn $\quad 74$

6 Logic and Ordinary Language 77

I. Formal semantics 77

2. Formal and natural languages 78

3. Formal semantics and verificationism 80

4. Obstacles to regimentation $8 \mathrm{I}$

5. Regimentation and ontology $\quad 87$

6. Intensions and modality 90

7 Meaning, Translation and Ontology gb

I. Quine and verificationism 96

2. Analyticity and synonymy 98

3. Defending the dogmas 101

4. Meaning and translation 104

5. Naturalism and relativism 108

6. Some paradoxes of radical translation 1 I 2

7. Stimulus meaning and observationality, II3

8. Linguistic autonomy and the bilingual speaker 117

9. Pelicans and half-brothers $\quad 120$ 
8 Truth and Interpretation

I. Meaning and $\mathrm{T}$-sentences

2. Radical interpretation

3. A critique of radical interpretation

9 Naming, Necessity and Natural Kinds

I. Realism and indexicality

2. Proper names and criteria of identity

3. Naming and necessity

4. Identity and rigid designation

5. Necessary-contingent: a priori-a posteriori

6. Baptism and criteria

7. Deixis and natural kinds

I 54

8. Causality and description

Ibo

III Communication and Intention $\quad \mathrm{I}_{6} 3$

Io Speech Acts

I. Language and action $\quad \mathrm{I}_{5}$

2. Speech acts

168

3. Speech acts and meaning

171

4. The anatomy of promising

173

5. Reference and predication

I I Meaning and Speakers' Meaning

I. Utterers' intentions

2. The standard counter-examples

I 85

3. Intention and convention

IV Language and the World

I 2 Interlude: Stalemate and Revision

I. Strawson's 'Homeric struggle'

2. Names and sentences

3. Revising the options

4. Frege and Wittgenstein 
13 Objects and the Determinateness of Sense 209

I. Metaphysics and meaning 209

2. Determinateness of sense 2 I I

3. The autonomy of the sentential sign 213

4. Negation, sense and the picture theory 216

5. Frege and the Tractatus 219

6. Saying and showing $\quad 223$

7. The breakdown of the Tractatus 224

I4 Meaning and Use 227

I. The problem of colour $\quad 227$

2. Negation and possibility 230

3. Propositions and yardsticks $\quad 23^{2}$

4. The transition to 'use' 233

5. Language games and 'the continuity of the given' 236

6. Language games, truth-conditions and linguistic autonomy $24^{6}$

7. Language games and objects $\quad 249$

8. Criteria and confirmation 250

Notes and References $\quad 259$

$\begin{array}{ll}\text { Bibliography } & 269\end{array}$

Index 296 


\section{Preface}

I was asked by Professor D. J. O'Connor, some years ago, to write for Macmillan a short introduction to the philosophy of language. I promised to do so, and was foolish enough to think that it would be quite easy to write such a book. I discovered my mistake. The present book, rather later and rather longer than I originally intended, is the outcome of that promise.

Philosophical discussion of language this century has been almost conterminous with philosophy itself. (It is often supposed that this is true only of philosophy in English-speaking countries and that continental European philosophers are properly above such demeaning and unphilosophical concerns. Those who think this have not read Husserl's Logical Investigations, or Merleau-Ponty's Le Prose du monde.) There is thus a bewildering variety and quantity of philosophical writing about language and it does not, even within the loose collection of philosophical outlooks called analytical philosophy, exhibit community of what is called 'approach'. To the uninitiated reader the writings of Donald Davidson and those of, say, the later Wittgenstein would scarcely appear at first sight to be contributions to the same discipline, let alone to the same discussion.

One solution to the problem of representing this diversity would have been to make the book a catalogue, or book of sketches, devoting a chapter to each major writer but not paying too much attention to the connections, or the gulfs, between them. This would have been easy, but ultimately unhelpful to the reader, whose false sense of familiarity with each writer would not go very deep. And I think it would have involved a misrepresentation of the subject. There are connections which bind the writings grouped under the heading of philosophy of language together to form a single 'subject' and even a single discussion: it is just that they are complicated, ramifying and hard to state simply and clearly. 
The problem was therefore to find a thread in the labyrinth. In the end I chose three. The first is the current dispute between those - a very diverse group in themselves - who think that the concept of truth is the key to the understanding of meaning, and those who think that meaning has more to do with the implicit conventions by appeal to which speakers understand each other's intentions in concrete contexts of communication. The second is the problem of the autonomy of language and the creativity of language use: the fact that speakers of a language are able to read off, simply from the sentential sign, the meaning and syntactic structure of sentences they have never encountered before. The third is the fate of verificationism as a theory of meaning. In terms of these three topics, which are related to one another in many ways, I have tried to give the book a firm spine of argument, around which to group apparently diverse and unrelated discussions so that their status as contributions to a single discussion becomes, I hope, rather clearer.

One considerable problem which the book presented was the treatment of Wittgenstein. Wittgenstein is arguably the greatest philosopher to have written this century about language. At the same time his influence on current philosophy of language is comparatively slight. A fairly common conventional view of his work is roughly that the Tractatus Logico-Philosophicus contains an early and outmoded realism, and that his later work progresses by way of a swiftly discarded, or at any rate publicly disavowed, verificationism to a generally 'operationalist' theory of meaning founded on an obscure and largely unexplained notion of a criterion or rule of use.

This view is, I think, wholly mistaken, and its prevalence serves to distract attention from a writer of genius who in fact, I believe, addressed the central concerns of present-day philosophy of language.

The best, and indeed the only way, to counteract this view seemed to be to present Wittgenstein's views in their proper stages of development from one another and from the work of Frege. To do this properly, however, would be an enormous exegetical task, and one which it would be quite impossible to attempt within a book of this length. I therefore had to choose between the alternatives of leaving Wittgenstein out, offering a guarded and conventional account of his work which would divorce him from the mainstream of philosophical discussion of language, or giving a very bald and crude sketch of how I believe Wittgenstein should be read. 
With some trepidation I have chosen the third, as the least unsatisfactory, of these options, and offer such a sketch in the concluding chapters of the book. For reasons of space I have made no attempt either to address the now quite large exegetical literature on Wittgenstein or to acknowledge, except in the Bibliography, the multifarious sources, in that literature, of my own interpretation.* I hope, however, that these chapters, despite their manifest defects, may serve some useful purpose in suggesting a reading of Wittgenstein which brings his work back into connection with current concerns.

The book as a whole is intended to make things as clear as possible for undergraduate and graduate students of philosophy, and to that end I have tried to cut out digression and to restrain technicality and exuberance of style. But I hope that it will also prove useful to linguists or psycholinguists, for example, who want to find out, without exorbitant expenditure of time and patience in reading, what philosophers have to say about language. And of course I hope that other philosophers will find something of interest in it.

It is only fair to such readers to let them know at what points my own ideas have crept into the discussion. The main areas of originality - or idiosyncrasy - in the book are: the discussion of the autonomy of language in chapter $I$ and the use made of this in chapters 7 and 8 to construct a critique of Quine and Davidson; some parts of the discussion of Locke and Russell in chapters' 2 and 3; the theory of promising as a contractual relationship, advanced in chapter I I; and to some extent, of course, the treatment of the development of Wittgenstein's thought in chapters 13 and I 4 . The general argument, or drift, of the book also represents my own opinion, but that can relatively easily be disentangled from the discussions of particular writers and schools.

The bibliography is as full as I could make it within reasonable bounds of length, and I have added a select bibliography of further reading for each of the main divisions of the text.

Sections of the book have been read to a variety of audiences over the past few years, and I have profited a good deal from the subsequent discussion as well as from numerous discussions with individual colleagues and students. Those friends and colleagues who have

*My treatment of naming and 'objects' in the Tractatus, for example, owes a great deal to Hidé Ishiguro's excellent paper 'Use and Reference of Names', in Winch ( 1969 ). 
helped to save me from error include Roy Edgley, Timothy Sprigge, Benjamin Gibbs, Barbara Lloyd and Aaron Sloman at Sussex; Julius Kovesi, Stewart Candlish, Graham Priest, Hartley Slater and Richard Borthwick at the University of Western Australia; Tony Coady and Brenda Judge at the University of Melbourne; Peter Herbst, Michael Stocker, Stanley Benn, Genevieve Lloyd, William Godfrey Smith and Maurita Harney at the Australian National University; David Angluin at the North London Polytechnic; in Oxford, Jerome Bruner; at the University of Lille III, Noël Mouloud and Charles Galperin. Such errors as remain are no fault of theirs.

Parts of the book were conceived or written during periods when I was, successively, a Leverhulme Research Fellow, a fellow of the Humanities Research Centre at the Australian National University and a visitor at the University of Western Australia. I wish to express my gratitude to all these institutions, and to the University of Sussex, which generously granted me leave on each occasion.

I owe a special debt of gratitude to Lee Carter of the University of Western Australia, the best secretary I have ever had, who typed the manuscript in record time, with flawless accuracy and efficiency.

Finally, the book would not have been completed without the love and support of my wife, who with unfailing generosity forgave all that the wives of writers have to put up with.

Falmer, Sussex

B. H.

January 1979 